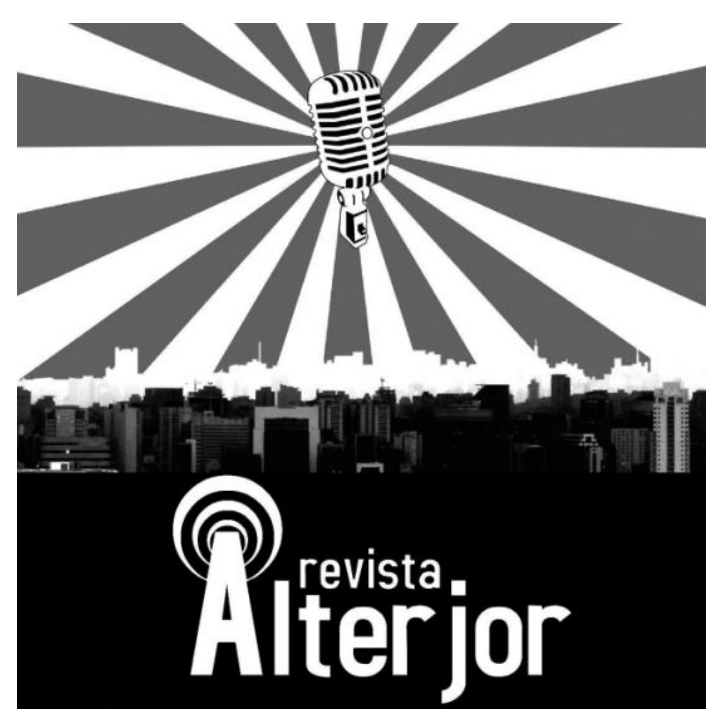

\title{
OS AGROTÓXICOS: PERIGOS E INDIFERENÇA NA MÍDIA HEGEMÔNICA
}

\author{
Andreia Terzariol Couto ${ }^{1}$
}

RESUMO: A crise ambiental revelada pelas mudanças climáticas traduz-se em secas, inundações, incêndios, aumento da temperatura e do nível do mar, crise alimentar, e por trás dessa realidade está a ação humana, exacerbada no Antropoceno. Paralelamente, no Brasil, evidencia-se a utilização de um modelo econômico de produção de commodities para exportação, ambientalmente destrutivo, sendo uma das características desse modelo o uso intensivo de agrotóxicos, que, por sua vez, extrapolam o ambiente do agronegócio e chegam às culturas alimentares. Sendo uma das principais premissas do jornalismo seu comprometimento com o interesse público, não se percebe na mídia hegemônica um movimento de debate sobre essas questões, tampouco um comprometimento em esclarecer população sobre esses assuntos.

PALAVRAS-CHAVE: Jornalismo Ambiental. Mudanças climáticas. Mídia hegemônica. Agrotóxicos. Antropoceno.

\begin{abstract}
The environmental crisis revealed by climate change translates into droughts, floods, fires, increase in temperature and sea level, food crisis, and behind this reality is human action, exacerbated in the Anthropocene. At the same time, in Brazil, there is evidence of the use of an environmentally destructive economic model for the production of commodities for export, and one of the characteristics of this model is the intensive use of pesticides, which, in turn, extrapolate the agribusiness environment and reach the food crops. Since one of the main premises of journalism is its commitment to the public interest, a movement of debate on these issues is not perceived in the hegemonic media, nor a commitment to clarify the population on these issues.
\end{abstract}

KEYWORDS: Environmental Journalism. Climate changes. Hegemonic media. Pesticides. Anthropocene.

${ }^{1}$ Pós-doutoranda da Universidade de São Paulo. E-mail: andreiatcouto@usp.br

\section{Revista ALTERJOR}

Grupo de Estudos Alterjor: Jornalismo Popular e Alternativo (ECA-USP)

Ano 12 - Volume 01 - Edição 25 - Janeiro-Junho de 2022

Av. Professor Lúcio Martins Rodrigues, 443, Cidade Universitária, São Paulo, CEP: 05508-020 


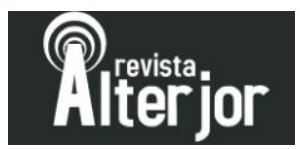

\section{Introdução}

Leonardo Megarejo ${ }^{2}$ é Engenheiro Agrônomo pela Universidade Federal do Rio Grande do Sul, e possui larga experiência na pesquisa agrícola, agroecologia, avaliação de riscos com OGMs - Organismos Geneticamente Modificados - reforma agrária, desenvolvimento rural, extensão rural, áreas em que se especializou no decorrer de seu mestrado em Economia Rural (UFRGS) e no Doutorado em Engenharia de Produção (UFSC). Além da área acadêmica, foi representante do Ministério do Desenvolvimento Agrário na CTNBio, presidente da AGAPAN - Associação Gaúcha de Proteção ao Ambiente Natural, ONG brasileira dedicada à luta em defesa do meio-ambiente, coordenador do GT sobre Agrotóxicos e Transgênicos e vice-presidente regional da Associação Brasileira de Agroecologia. Há anos dedica-se à pesquisa sobre os impactos dos agrotóxicos, coordenando e fazendo parte do Fórum Gaúcho de Combate aos Impactos dos Agrotóxicos, além de cooperar com a Campanha Permanente Contra os Agrotóxicos e pela Vida e do Movimento Ciência Cidadã. É pesquisador e professor colaborador do curso de especialização profissional em Agro ecossistemas da UFSC.

Embora tenha aumentado consideravelmente o foco sobre as pautas ambientais, o público em geral ainda carece de publicações regulares na grande mídia que reflitam e debatam de forma sistemática importantes questões da realidade, realidade essa que está visivelmente se transformando e afetando a todos de uma maneira geral. Não é mais possível ignorar os riscos a que estamos expostos como reflexo direto das mudanças climáticas. O aquecimento global tem mudado não apenas a condução natural e a ordem das regulamentações da natureza, como tem afetado a vida de quem vive e produz dependendo diretamente dos ciclos naturais da agricultura. Além disso, o cidadão, de forma ampla, e aqui no Brasil especialmente, sofre duplamente com as transformações não apenas ambientais como com a forma de produção: o uso intensivo de eufemisticamente dos chamados "defensivos agrícolas" estão fartamente presentes na alimentação do povo brasileiro e as consequências desse consumo cotidiano são as

\footnotetext{
${ }^{2}$ Informações obtidas através de entrevista realizada no dia 17/11/2021 pelo Google Meet, como parte das entrevistas para o projeto de pós-doutorado em relação à percepção pública sobre Ciência e Tecnologia em temas como agrotóxicos e os sistemas aquífero Guarani e Amazônico.
}

Revista ALTERJOR

Grupo de Estudos Alterjor: Jornalismo Popular e Alternativo (ECA-USP)

Ano 12 - Volume 01 - Edição 25 - Janeiro-Junho de 2022

Av. Professor Lúcio Martins Rodrigues, 443, Cidade Universitária, São Paulo, CEP: 05508-020 


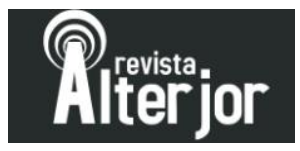

piores possíveis. Além da ingestão do veneno na forma de agrotóxicos, ele está presente de maneira insuspeita para a maioria da população: na água que consome. A contaminação por agrotóxicos de recursos hídricos considerados pela população como protegidos, os aquíferos, além das fontes minerais é uma realidade comprovada.

Enquanto o discurso oficial defende largamente, em publicidade na grande mídia e em lobbies no Congresso, tenta-se fazer frente a esse discurso através de ações como a da Associação Brasileira de Agroecologia, que mostra que o manejo de culturas pautadas em formas naturais sem a utilização de veneno é totalmente possível. A dificuldade não se encontra na produção em si, mas no grande capital que defende o agrotóxico, utilizando o mote de "que a saída para a alimentação mundial é o agronegócio", colocando o cultivo agroecológico como economicamente inviável em larga escala. Porém, em contraposição ao discurso veiculado nos principais veículos de imprensa, sobre a grande produção que alimenta o país, começa-se a modular uma imprensa alternativa, principalmente através dos canais eletrônicos, para debater as raízes do emaranhado político e econômico que envolvem agronegócio, agrotóxicos, política, economia. Porque o discurso hegemônico não menciona que as grandes lavouras monocultoras, especialmente as de soja e cana, não estão direcionadas para os pratos brasileiros, sendo exportadas in natura onde servirão de base para a produção de ração animal, enquanto a cana é matéria prima para o etanol. E que o agricultor familiar, o verdadeiro produtor de alimentos, não apenas fica ao largo das tomadas de decisão nas políticas públicas para o setor, como não recebe as devidas fatias do bolo em relação ao financiamento público.

Como diz Leonardo Melgarejo, há uma necessidade em se perceber a natureza através de uma percepção mais holística, mais abrangente, papel que a agroecologia realiza de forma perfeita, porque nos leva à necessidade de examinarmos as relações e não os pontos focais, e isso diz respeito aos agrotóxicos, sobre os transgênicos, mas principalmente sobre os mecanismos de comunicação. Para o pesquisador, ao tratarmos da percepção pública sobre Ciência e Tecnologia, estamos levando o foco diretamente para questões mais amplas, como as alterações climáticas, às alterações do desenvolvimento de modos de produção, em especial em países como o nosso, 


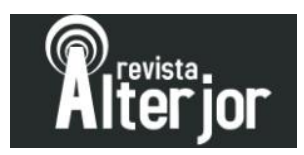

dependentes da exportação de matérias primas de baixo valor agregado. Segundo Melgarejo, a expressão que sintetiza isso é aquela da colonização epistemológica, que nos estabelece filtros impedindo-nos de enxergar a realidade através das suas relações, considerando, por exemplo, que o PIB do agronegócio nos faz bem, quando na sua raiz está o envenenamento da água, a destruição dos ecossistemas, a ruptura de serviços ambientais prestados por organismos que estamos destruindo antes de conhecer.

\section{Entrevista}

Andreia Couto - Gostaria inicialmente que o senhor comentasse sobre o comportamento da grande mídia, que, dado o seu dever primeiro de comprometimento com a verdade e com o interesse público, atua, ao contrário, em favor do interesse do público, do agronegócio.

Leonardo Melgarejo - Sim, nós consideramos bastante normal que cada um dos seres do planeta procure influenciar o ambiente segundo a sua perspectiva, segundo o seu modo de vista. Mas nós temos regras comuns. Os direitos humanos são regras fundamentais que deveriam estabelecer uma barreira na busca da configuração do planeta segundo os interesses de cada um e há um desbalanceamento muito grande entre a possibilidade de ocultar e de desrespeitar esses compromissos estabelecidos, como por exemplo, os direitos humanos fundamentais. E no caso do agronegócio, principalmente em países que têm uma posição subalterna na geopolítica internacional, que é o nosso caso, as distorções acabam colonizando a forma de ver das pessoas. Veja o exemplo do choque mais díspar, nesse caso da construção de uma interpretação sobre o agronegócio e sobre os seus impactos, associado ao filme do Sílvio Tendler, O Veneno está na Mesa, e que, segundo o Sílvio Tendler, custou 50 mil reais, foi feito com a colaboração de centenas de pessoas que deram seu depoimento sem cachê e a resposta ao Veneno está na mesa é essa campanha do Agro é Pop, que deve estar custando bilhões de reais. E que é de fato um esforço de desconscientização das pessoas às custas de recursos e utilizando como instrumento uma grande mídia que deveria se prestar mais à deslienação das pessoas do que essa ocultação dos problemas. Ainda esta semana o discurso do agro é pop foi de que as abelhas são "agro", quando nós estamos vivendo o colapso, a extinção das abelhas e outros polinizadores pelo uso dos agrotóxicos. Então, a responsabilidade deveria ser mais nossa, do cidadão comum, que se fosse mais bem esclarecido, se tivesse mais acesso às mídias independentes e responsáveis, poderia filtrar melhor suas decisões na hora de escolher os representantes da sociedade de tal maneira que nós não tivéssemos um governo como esse, que sem nenhum problema

\section{Revista ALTERJOR}

Grupo de Estudos Alterjor: Jornalismo Popular e Alternativo (ECA-USP)

Ano 12 - Volume 01 - Edição 25 - Janeiro-Junho de 2022

Av. Professor Lúcio Martins Rodrigues, 443, Cidade Universitária, São Paulo, CEP: 05508-020 


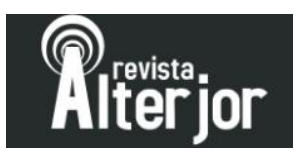

novo na agricultura, já autorizou mais de 1.300 venenos novos. Você poderia perguntar: e os venenos velhos, eles eram piores que esses, porque eles continuam sendo vendidos? E esses são melhores? Se são melhores, porque são maios baratos? E isso se torna claro, eles são mais baratos porque eles são proibidos em outros países, e essa proibição decorre dos impactos que provocam, que eles causam sobre os direitos humanos, que aqui são menos valorizados do que em determinados empreendimentos relacionados à possibilidade de ganho no curto prazo.

Andreia Couto - O senhor considera, dado que a mídia hegemônica está atrelada ao poder econômico, que essa seria uma saída para a conscientização do grande público, o jornalismo popular, o jornalismo comunitário, alternativo, digital?

Leonardo Melgarejo - Eu acho que isso vem acontecendo e creio que a tomada de consciência, que é crescente, decorre desses esforços, que, via de regra são iniciativas que têm uma sobrevida muito curta e que se sucedem porque eles acabam enfrentando muitos problemas judiciais, muitas acusações, o que inviabiliza a manutenção durante grandes períodos. Então essa mídia alternativa ela também não tem condições econômicas de fazer pesquisas de fundo. Creio que seja de fato uma solução, mas que a alternativa para a humanidade está na educação pública e que precisaríamos de governos mais responsáveis com relação à desalienação da população, o que implicaria em processos de informação.

Eu não acredito que exista algum agricultor no Brasil - desses que utilizam bastante agrotóxico - que tenha consciência de que alguns agrotóxicos - talvez um dos herbicidas mais usados na lavoura de milho, que é uma das mais importantes - se chama Atrazina $^{3}$ - e esse herbicida, que é produzido pela Singenta, e que agora foi comprado pela empresa chinesa ChemChina - causa alteração hormonal grave, que em testes com alguns anfíbios e peixes, a alteração hormonal leva à feminilização completa. O indivíduo nasce macho, se torna fêmea fértil. E esse mesmo tipo de alteração hormonal associado à feminilização tende a ser extensivo a outros seres que nós não

\footnotetext{
${ }^{3}$ De acordo com o portal Por trás do Alimento, a Atrazina faz parte dos venenos considerados altamente perigosos pela Pesticide Action Network (PAN). "A Atrazina é classificada pela União Europeia como uma substância com evidências de causar distúrbios endócrinos, que afeta o sistema hormonal. Sua classificação no Brasil é III. (Medianamente Tóxico)

Autorizado no Brasil. Proibido na União Europeia

Percentual de detecção na água do Brasil: 84\% (30.055 detecções de 35.577 testes feitos em todo o país)

Número de vezes em que a concentração detectada estava acima do limite Brasileiro: 16

Número de vezes que a concentração detectada estava acima do limite da União Europeia: 3.914

Limite máximo permitido na água do Brasil: $2 \mu \mathrm{g} / \mathrm{L}$

Limite máximo permitido na água da União Europeia: $0.1 \mu \mathrm{g} / \mathrm{L}$

https://portrasdoalimento.info/2019/04/12/conheca-os-27-agrotoxicos-encontrados-na-agua-que-

abastasse-as-cidades-do-brasil/
}

Revista ALTERJOR

Grupo de Estudos Alterjor: Jornalismo Popular e Alternativo (ECA-USP)

Ano 12 - Volume 01 - Edição 25 - Janeiro-Junho de 2022

Av. Professor Lúcio Martins Rodrigues, 443, Cidade Universitária, São Paulo, CEP: 05508-020 


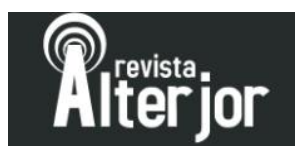

estamos avaliando. Eu não acredito que algum agricultor que tenha consciência disso se permita jogar no seu estabelecimento veneno desse tipo que vai parar na água, que vai contaminar sua esposa quando vai lavar a roupa dele.

Andreia Couto - Eu concordo com o senhor. Mas o pequeno agricultor, nesse Brasil profundo, que nem teve acesso à alfabetização, ele pode não saber, da mesma forma que ele talvez nem tenha como ler os rótulos das embalagens dos venenos, descarta às vezes, por não saber as consequências, as embalagens de qualquer maneira, contaminando seus recursos hídricos. Agora, o grande produtor, o médio, ele sabe que está envenenando todo mundo, não sabe?

Leonardo Melgarejo - Eu acredito que tem muitos que não sabem; tem muitos que não acreditam; e tem outros que não dão importância para isso.

Andreia Couto - Os negacionistas, então.

Leonardo Melgarejo - É. Tem os negacionistas. Eu tenho colegas de faculdade, que fizeram agronomia comigo há quase quarenta anos atrás e que são pessoas bemsucedidas na vida sob o ponto de vista da renda, gente que viaja bastante pelo mundo, e que não percebe que há uma relação de causa direta entre tudo o que acontece no planeta. Simplesmente não percebem que o avanço do agronegócio no Brasil associado à expansão da soja está associado à destruição do ecossistema amazônico, está associado à seca aqui no Sul, que as análises de agua no Brasil mostram que a nossa água é venenosa se for comparada com a água que é considerada potável na Comunidade Econômica Europeia. E eles vivem aqui, passam as férias lá. Mas vivem aqui e não percebem essas relações. Então é um problema de educação.

Andreia Couto - Não percebem ou - já que são pessoas tão esclarecidas - às vezes é mais conveniente não querer ver.

Leonardo Melgarejo - É isso mesmo.

Andreia Couto - Eu acredito também bastante nessa questão da educação. Esse ano comemoramos o centenário de Paulo Freire. E a nossa educação pública está totalmente destroçada, ela ainda não consegue abrigar uma discussão sobre a educação ambiental, que seria o ideal, não é? Começar com as crianças, que são replicadoras, e que vão vivenciar toda essa tragédia futura.

Leonardo Melgarejo - Sim, é exatamente isso. São vários os problemas da nossa civilização e que são associados à distorção de percepção. Não há dúvida de que o

\section{Revista ALTERJOR}

Grupo de Estudos Alterjor: Jornalismo Popular e Alternativo (ECA-USP)

Ano 12 - Volume 01 - Edição 25 - Janeiro-Junho de 2022

Av. Professor Lúcio Martins Rodrigues, 443, Cidade Universitária, São Paulo, CEP: 05508-020 


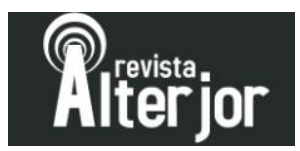

transporte particular, que o carro privado é um problema e é uma espécie de câncer porque desenvolve uma cadeia de necessidades. E o consumo de carne é algo que também deve ser questionado. Não é que a gente deva parar de comer carne, mas sem dúvida nós temos que suspender esses processos de criação em campos de concentração que geram animais doentes, que nos fazem consumir muito antibiótico, que estão selecionando bactérias tolerantes a todos os tipos de antibióticos. Isso tem que ser modificado. Mas todos querem comer carne. Por quê? Porque quando crianças, as crianças não percebem que seu amor pelos bichinhos é oposto ao seu prazer pelo coraçãozinho de galinha. Vinte coraçõezinhos de galinha num espeto. As crianças não percebem isso. Não percebem porque o processo de educação as aliena em relação a essas relações. Bastava que na educação de crianças se estabelecesse essa relação entre o consumo de carne, as implicações do consumo de carne e os bichinhos de pelúcia que eles recebem para acarinhar. Bastava o estabelecimento dessa relação para que nós conseguíssemos alterar essa crise. Já o caso do transporte é mais complicado. Nós precisaríamos ter investimentos para o transporte público. Não seria uma questão de conscientização da população como no caso do consumo de carne, mas seria uma questão de priorização. Existem pessoas que trocam de carro todo ano para se manter na linha. É uma produção de lixo descomunal.

Andreia Couto - Assim como trocam de celular, de outras coisas. O Davi Kopenawa chama o homem branco de o "homem das coisas", que está sempre produzindo coisas e depois não sabe o que fazer com elas. O senhor falou do consumo da carne, eu acredito nisso, acho que as ações individuais, quando em conjunto, podem ter um impacto positivo. Não só no consumo da carne, e a gente tem mesmo que pensar sobre isso, mas como um todo, porque o padrão de consumo hoje no mundo capitalista, voraz, de produção, produção, produção, está levando a esse colapso. Então o consumo consciente, a nossa postura como consumidores é importante.

Leonardo Melgarejo - Pleno acordo. Eu usei o exemplo da carne porque é um exemplo fácil, porque eu tenho uma netinha, e com a minha netinha é fácil. Eu tenho filhas adultas e as minhas filhas adultas não tomavam refrigerante quando eram crianças e isso era uma coisa estranha, porque elas iam na festinha das coleguinhas e pediam água, e inclusive era algo mal visto, era considerado um elitismo besta. Mas se acostumaram a crescer sem tomar refrigerante. E essa minha netinha agora eu tenho absoluta certeza que eu vou influenciá-la a não dar preferência à carne. Não significa não comer. Significa não pensar o que nós vamos almoçar hoje e esse almoçar hoje ser frango, peixe ou carne.

Revista ALTERJOR

Grupo de Estudos Alterjor: Jornalismo Popular e Alternativo (ECA-USP)

Ano 12 - Volume 01 - Edição 25 - Janeiro-Junho de 2022 Av. Professor Lúcio Martins Rodrigues, 443, Cidade Universitária, São Paulo, CEP: 05508-020 


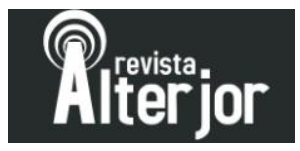

Andreia Couto - Eu acho importante, tenho refletido bastante em relação a isso e eu estou parando, na verdade. Com a carne vermelha já parei e agora nesse final de ano termino com as outras. Porque eu acho que seria uma incoerência também trabalhar com todas essas questões e agir de uma maneira completamente oposta.

Leonardo Melgarejo - Eu admiro muito, respeito, e confesso que tenho dificuldade. Eu consigo reduzir o consumo. Consegui parar de fumar, foi terrível, foi muito difícil parar de fumar. Eu perdi uma parte de mim mesmo porque os meus hábitos eram associados àquele vício. Então eu não quero parar de comer carne, mas quero comer menos. Eu participei desse processo de educação viciante que me trouxe a ser fumante e agora não sou mais e que me fez consumidor de carne e eu agora sou menos. Mas nesse caso o prazer pode ser equacionado pensando assim: eu andei lendo sobre isso essa semana. Os ecossistemas se desenvolvem especializando e diferenciando os indivíduos que neles habitam. E os mamíferos de grande porte, o boi, por exemplo, eles são fundamentais para a biodiversidade da flora no seu espaço. Porque o boi vai lá, come o azevem, ${ }^{4}$ leva a semente, bosteia mais adiante e está plantando. A retirada dos mamíferos de grande porte está associada a uma desorientação no ecossistema que inclusive amplia os riscos de incêndio, porque o acúmulo de massa seca combustível, é maior se tu não tiver esses bichos grandes que fazem a coleta. Tudo isso que estou dizendo para afirmar que nós precisamos de pecuaristas familiares, agricultores pequenos com seus três, quatro bois, com as suas vaquinhas e esses bichos envelhecem, eles vão ter que vender em algum momento. Então a gente pode comer esses bichos. Eu penso assim.

Andreia - É, eu imaginei que eu parando de comer carne vermelha eu iria comer um franguinho caipira de vez em quando, meu sogro é sitiante, mas aí eu chego lá e vejo as galinhas ciscando, e não, não tenho coragem!

Leonardo Melgarejo - Eu entendo bem isso. Eu estou montando um galinheiro aqui em casa, e o objetivo são os ovos. Mas os ovos vão dar a galinha e vão dar o frango. E o que eu vou fazer com o frango? Eu vou comer. Essas contradições nos permitem procurar imaginar que esses animais todos, assim como nós, precisam de uma vida saudável, com um espaço com sol, eles não podem viver em campos de concentração e serem infelizes. Eles não sendo infelizes e tendo uma vida saudável eu acho que na distribuição da cadeia alimentar esse sacrifício pode ser tolerado, em pequena escala.

\footnotetext{
${ }^{4}$ Azevem (LoliummultiflorumLam) é uma espécie de forrageira. https://www.embrapa.br

Revista ALTERJOR

Grupo de Estudos Alterjor: Jornalismo Popular e Alternativo (ECA-USP)

Ano 12 - Volume 01 - Edição 25 - Janeiro-Junho de 2022

Av. Professor Lúcio Martins Rodrigues, 443, Cidade Universitária, São Paulo, CEP: 05508-020
} 


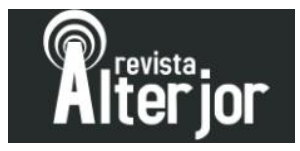

Andreia Couto - Aqui na minha região, eu moro em Campinas, tem uma fazenda de orgânicos que cria galinhas e o slogan da criação de galinhas é "galinha feliz", porque elas vivem soltas... E são chamadas de galinhas felizes.

Leonardo Melgarejo - E devem ser. Eu não acredito que elas tenham preocupações filosóficas e que elas sonhem com o paraíso das galinhas. É comer, viver...

Andreia Couto - E não têm aquele stress da gaiola, do confinamento, aquela coisa apertada, tristíssima, não é? E o transporte, na estrada a gente vê caminhões passando com aquelas gaiolas amontoadas, é horrível! Eu não sei se ainda tem, mas deve ter, os "caminhões de boi", a gente chamava assim na infância, quando viajava de carro e eu achava aquilo um horror! Esse sistema alimentar, hoje eu vejo assim, ele é pautado em muita crueldade do ser humano que vê os animais como coisas. É muita maldade!

Leonardo Melgarejo - Sim, é muita maldade. O Brasil está exportando boi vivo, os animais vão empilhados em gaiolas para serem mortos no exterior. Quando eu estava na agronomia, visitei um frigorífico/matadouro da Sadia e foi a visão mais próxima do inferno que eu consegui ter.... Aqueles bichos gritando, pendurados pelas pernas, uma coisa horrível, horrível! Então eu procuro não comprar esses animais que não sejam criados de uma maneira mais próxima de ser feliz e nós temos os selos orgânicos que nos permitem acreditar nisso.

Andreia Couto - A carne "verde", não é?

Leonardo Melgarejo - A "carne verde". E isso tem para tudo, para todos os animais, em supermercados mais elitizados, é verdade. Acho que nós vamos chegar nesse ponto, quando nós amadurecermos mais como humanidade.

Andreia Couto - Se tivermos tempo, não é?

Leonardo Melgarejo - Creio que o Krenac é um dos filósofos, talvez mais do que isso, ele seria uma dessas pessoas que antecipam a realidade, tipo, os profetas do passado, nós temos o profeta do presente nos apontando caminhos.

Andreia Couto - Eu recentemente adquiri o livro dele, Ideias para adiar o fim do mundo. Eu sempre que posso vejo suas palestras, entrevistas, acho ele uma pessoa fantástica. Assim como esses representantes que conseguem ter essa fala, que conseguem ser ouvidos, os representantes dos povos da floresta. Porque é uma tragédia o que está aí e o que me incomoda nisso tudo, principalmente em relação ao garimpo

Revista ALTERJOR

Grupo de Estudos Alterjor: Jornalismo Popular e Alternativo (ECA-USP)

Ano 12 - Volume 01 - Edição 25 - Janeiro-Junho de 2022

Av. Professor Lúcio Martins Rodrigues, 443, Cidade Universitária, São Paulo, CEP: 05508-020 


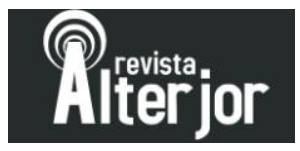

em terras indígenas, nas terras Ianomâmi, é que nós estamos assistindo isso, e não há uma reação de fato, muito pelo contrário, o governo incentiva, estamos assistindo a um genocídio dos povos originais.

Leonardo Melgarejo - Olha, Andreia, eu vou te dar um outro dado, não sei se tu já chegou na tua pesquisa, mas que na minha já apareceu, é de que a discussão da busca de energia para manter o sistema econômico girando ela aponta para uma conversão, para uma transformação para que nós usemos aqui no Brasil a energia eólica e a energia solar. Isso também demanda materiais e também demanda mineração. Esses minérios estão embaixo da floresta amazônica. Tem de tudo lá. Nos outros lugares já foram minerados, então... existe uma tendência econômica do mesmo sistema capitalista que justifica a destruição dessas reservas biológicas que são o tesouro da humanidade para a conversão da energia fóssil para outras formas de energia utilizando os minérios que estão lá. Os discursos são todos muito sedutores.

Andreia Couto - É incrível, isso, essa questão do discurso. Como o lobby, inclusive do agronegócio, ele é articulado. Como da porta-voz do agronegócio, a senadora Kátia Abreu. Ela, inclusive dá risada quando alguém fala que agrotóxico faz mal; ela já afirmou que pobre tem que comer veneno, sim, que é a única forma de alimentar o mundo; que hoje as pessoas estão vivendo mais e são mais jovens; que o agrotóxico é que vai propiciar a alimentação do mundo. E esse discurso, que não deixa de ser articulado, de uma certa maneira, ele ganha a mídia, não é? No Roda Viva que ela participou, em abril desse ano, que é um espaço que poderia ser utilizado para esclarecer as pessoas sobre os perigos, não! Os entrevistadores ficaram ali meio que passando o pano. Agora, nós, os pesquisadores, temos que fazer frente a esse discurso, desmontar esse discurso.

Leonardo Melgarejo - Sim. Eu sou otimista. Sou otimista, mesmo porque ser pessimista não adianta, não é? Já sai derrotado. Ontem eu participei de uma discussão num outro grupo sobre esse mesmo tema e usei o argumento que eu mais gosto de utilizar a respeito das transformações que queremos que sejam qualitativas. As transformações qualitativas, na verdade, elas decorrem de um processo quantitativo, de acumulação de energia. A imagem da água. Tu bota a água pra ferver, ela é líquida, ela é líquida e de repente, quando passa de 99 para os 100 graus, a realidade muda. E nós, quantitativamente, estamos crescendo com essa consciência no planeta. Estamos crescendo a ponto de que a Kátia Abreu, que é uma pessoa muito influente, ela tem essa vulnerabilidade que tu percebe, que eu percebo e que muitas pessoas percebem. Daqui a algum tempo isso vai ser inegável para todo mundo. Esses charlatões não vão conseguir se manter nessa linha. Veja o Papa, o representante da Igreja Católica, já mudou o seu

Revista ALTERJOR

Grupo de Estudos Alterjor: Jornalismo Popular e Alternativo (ECA-USP)

Ano 12 - Volume 01 - Edição 25 - Janeiro-Junho de 2022

Av. Professor Lúcio Martins Rodrigues, 443, Cidade Universitária, São Paulo, CEP: 05508-020 


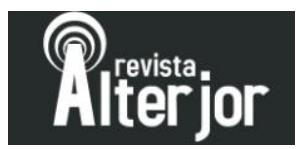

discurso. Tá certo, ele é uma pessoa especial, mas a igreja precisava mudar o seu discurso, porque esse nível de consciência está crescendo. O Krenac, ele é o que é porque há uma demanda, uma necessidade desse tipo de fala. Então nós estamos acumulando quantitativamente a energia para que se dê essa mudança qualitativa que tu e eu esperamos, antes daquilo que o Krenak chama de fim do mundo, porque nós estamos perto do fim do mundo mesmo, a extinção dos insetos, das abelhas ... a seca: vejo só, o Rio Grande do Sul está tendo secas maiores agora e isso está associado à destruição da floresta Amazônica, isso está bem mapeado. A grande questão é: para onde vai essa água? Porque a água é a mesma que sempre existiu no planeta, não se fabrica água, a água não desaparece. Ela vai para as enchentes. Nós vamos ter dilúvios em lugares inesperados cada vez com maior frequência. Ao mesmo tempo que nós vamos ter a criação de desertos aqui no Rio Grande do Sul, temos um deserto em São João que está crescendo, vai virar um Saara, nós vamos ter dilúvios em outros lugares. Para resolver esses problemas, nós precisamos entender que o ecossistema do planeta é todo interligado, o que falta num lugar sobra no outro. E essa consciência é crescente. Não faz muito tempo foi publicado aí na literatura especializada que os pesquisadores lá no Tibete encontraram em camadas de gelo de 15 mil anos atrás vírus novos, ativos. Vinte e oito desses vírus novos eram totalmente desconhecidos pelo seu DNA, o que significa que eles foram patógenos de animais que não existem mais, deixaram de existir. Mas eles estão sendo descongelados, eles mantêm a sua capacidade de reprodução dentro de célula e eles vão encontrar um mundo sem defesa em relação a eles, sem sistemas imunológicos. $\mathrm{O}$ aquecimento global associado ao avanço da soja na área dos Ianomâmi, associada aos vinte mil garimpeiros que estão lá tocando o terror está abrindo também espaço para essas coisas novas, essas doenças terríveis, novas.

Andreia Couto - É o que se fala do derretimento do permafrost ${ }^{5}$ com o aquecimento global. O que será que vai sair dali?

\footnotetext{
${ }^{5}$ De acordo com o site do Instituto Geociências, da Unicamp, "PERMAFROST é termo em inglês que poderia ser traduzido livremente como "permanentemente congelado". Uma conceituação mais formal, como a apresentada pela API (International Permafrost Association), define permafrost como uma superfície que permanece a temperaturas abaixo de $0^{\circ}$ por pelo menos dois anos consecutivos e que pode ser constituída tanto por solo, como rochas, gelo, sedimentos e matéria orgânica. Sua ocorrência está ligada com ambientes periglaciais (ambiente que ocorre junto às áreas glaciais, nas regiões de degelo e circunvizinhas... (Glossário Geológico). Com base na descrição apontada pelo Glossário Geológico Ilustrado (2021), permafrost ocupam cerca de $20 \%$ da superfície terrestre e aproximadamente $1 / 3$ de sua totalidade está para degelar e em alguns lugares já encontram-se em pleno degelo (fenômeno causado pelo derretimento paulatino das massas de gelo e de neve existentes na superfície da Terra, provocado pelo aumento da temperatura ambiente)". O degelo do permafrost está diretamente ligado às mudanças climáticas. Ainda segundo o portal do IG, "por se tratarem de solos antigos eles contêm uma grande quantidade de vestígios da vida antiga que por sua vez, preservam no seu interior também grandes quantidades de gases como o dióxido de carbono e o metano". São ainda apontados dois fatores relevantes sobre o derretimento dessa superfície: Ainda de acordo com o IG, são apontados mais dois fatores de risco com o derretimento dessa superfície: 1 - "pesquisadores agora suspeitam que, para cada
} 
Leonardo Melgarejo - Exatamente, o que será que vai sair dali? As neves eternas do Kilimanjaro, o que vai vir de lá? O que está lá embaixo? Não sabemos. A leitura ecológica é que, como o planeta Terra é um ser vivo, formado pela articulação de todas essas formas de vida que nós temos, que buscam equilíbrio, e buscar o equilíbrio significa minimizar os danos daquelas fontes que são as mais perigosas, essa leitura mais apocalíptica, diz que a Covid-19 não mata cachorro, não mata gato, porque cachorro e gato não precisam ser eliminados. Ela está matando humanos. São questões sobre as quais deveríamos pensar.

Andreia Couto - Na verdade, professor, eu acho que todas essas questões ecológicas, em torno do aquecimento global e tudo o mais, nos levam, necessariamente, a questões filosóficas, a presença humana na Terra, e isso desemboca nesse modo de vida que nós temos, e se isso continuar, eu fico pensando, de um lado existe a conscientização, que pode crescer, mas por outro lado a sobrevivência na terra está pautada numa série de situações que é comer, viver, se deslocar e para isso a necessidade de se retirar recursos de algum lugar. Mesmo em relação a formas alternativas de energia, vai haver impacto. O senhor falou, por exemplo, sobre a energia eólica. Recentemente eu li que agricultores do Nordeste estão reclamando de alguns impactos gerados pelo barulho das hélices próximas às suas terras, um zunido constante e que eles não conseguem dormir e isso está afetando diretamente essas pessoas. A questão do carro elétrico, o que faremos com as baterias?

Leonardo Melgarejo - O que indica que nós temos que reduzir o crescimento de algumas facilidades para ter acesso a outras facilidades. Para ter acesso à galinha feliz tu vai ter que reduzir os grandes aviários, os empregos dos grandes aviários e assim sucessivamente para que se tornem competitivas, essa galinha feliz. E é essa a opção.

Existe um estudo da $\mathrm{Oxfam}^{6}$ que trata da pegada ecológica e associa as pegadas ecológicas aos níveis de renda e que permite discutir aquela história de que nós temos gente demais no planeta e essa gente demais precisa de comida. Porque esse estudo mostra que a pegada ecológica de $50 \%$ da população do planeta, os $50 \%$ inferiores em termos de nível de consumo não corresponde ao nível de consumo dos $10 \%$ mais ricos,

aumento de um grau Celsius na temperatura média da Terra, o permafrost possa liberar o equivalente a quatro a seis anos de emissão de carvão, petróleo e gás natural". (National Geographic, 2020); 2 - "Como consequência do derretimento do permafrost, os vetores de infecções mortais dos séculos 18 e 19 podem voltar, especialmente perto dos cemitérios onde as vítimas dessas infecções foram enterradas" (Boris Revich e Marina Podolnaya, pesquisadores da Academia Russa de Ciências, Moscou).

https://www.ige.unicamp.br/pedologia/2021/06/02/o-que-e-permafrost-e-por-que-se-importar/

${ }^{6}$ Oxford Committe for Famine Relief (Comitê de Oxford para Alívio da Fome).

Revista ALTERJOR

Grupo de Estudos Alterjor: Jornalismo Popular e Alternativo (ECA-USP)

Ano 12 - Volume 01 - Edição 25 - Janeiro-Junho de 2022

Av. Professor Lúcio Martins Rodrigues, 443, Cidade Universitária, São Paulo, CEP: 05508-020 
e que se tu reduzir o nível de consumo, o nível de desperdício, de produção de lixo dessas pessoas que trocam de carro todo ano, tu pode atender esses outros 50\%. Como se fosse mais econômico para o planeta eliminar os $3 \%$ mais ricos do que os $50 \%$ mais pobres, para gerar um equilíbrio. Portanto, a questão está na concentração de possibilidades de desperdício, não é nem na concentração de possibilidade de consumo, é de possibilidade de consumo mesmo, porque é possível atender as necessidades de todos. Os problemas da agricultura ecológica não são técnicos, eles são políticos, as vantagens dos venenos não são técnicas, elas são econômicas, estão tuteladas por interesses políticos. Então os problemas são aqueles como nós começamos a nossa conversa, o problema é de conscientização, de ocultação ou disseminação de informações que permitam a população de tomar decisões conscientes olhando para o longo prazo. O Davi Kopenawa e o Airton Krenak, os dois mencionam que o problema dos brancos, dos outros, dos nossos, é a ruptura do conceito plurigeracional, o desrespeito com os velhos e as crianças, porque se tu desrespeitar os velhos e as crianças, tu pode centrar uma visão de curto prazo, que é safra do ano. E eu acho que eles têm razão, por isso são profetas, eles têm razão. Precisamos recuperar uma visão de longo prazo porque ele é fundamental para o compromisso entre as gerações, que nós perdemos, não temos mais.

Andreia Couto - E eu acho que essa visão deles é semelhante com a de alguns povos na África, por exemplo, em que a própria questão do tempo, para eles, é pautada na natureza, o tempo que o milho vai levar para crescer, o tempo da chuva, o tempo que a semente vai brotar e tudo o mais e é sempre esse saber milenar que estabelece o equilíbrio, um equilíbrio que esse mundo em que vivemos, quebrou.

Leonardo Melgarejo - É muito bom esse nosso tipo de conversa, porque ele abre essas perspectivas. Teve um momento em que me chegou a informação sobre um fato interessante de que no passado, em muitas civilizações, as divindades femininas tinham igual poder que as divindades masculinas. Em algumas civilizações tinham um poder muito maior, aqui nos Andes a Mãe Terra, nas religiões africanas, a água, que é a base da vida, é uma divindade.

Andreia Couto - Alguns povos africanos chamam o continente de mãe África, porque nessas culturas a mãe tem um poder muito grande, muitas vezes é matriarcal, mesmo, ela cria os filhos, eles devem obediência a ela, é sob as asas dela que eles se criam.

Revista ALTERJOR

Grupo de Estudos Alterjor: Jornalismo Popular e Alternativo (ECA-USP)

Ano 12 - Volume 01 - Edição 25 - Janeiro-Junho de 2022

Av. Professor Lúcio Martins Rodrigues, 443, Cidade Universitária, São Paulo, CEP: 05508-020 


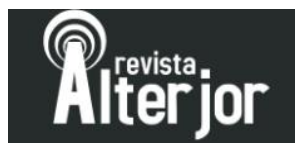

Leonardo Melgarejo - E isso faz muito sentido, assim como faz muito sentido a Txai, ${ }^{7}$ aquela menina indígena de 24 anos fazer aquele discurso maravilhoso. O poder feminino está retomando espaço num mundo destruído pelo poder masculino. E essa retomada de equilíbrio está associada, filosoficamente, à revalorização de divindades femininas. E com essa visão feminina, com o fato da gente ter hoje, hoje não, mas no futuro próximo a maior parte das juízas, não juízes. A maior parte das pesquisas, as mulheres estão ocupando esses espaços que antes eram reservados aos homens, gradativamente, e isso vai mudar a maneira de ver e de ser da sociedade. E acho muito bom, mesmo porque só tenho filhas e netas.

Andreia Couto - É interessante essa visão, vamos voltar lá para o mito das Amazonas, não é?

Leonardo Melgarejo - É possível!

Andreia Couto - E por falar em Amazonas, minha pesquisa pretende privilegiar alguns aspectos dos recursos hídricos, especificamente dos aquíferos do sistema Amazonas e Guarani, e o senhor, como é do Sul, o Sistema Aquífero Guarani pega uma grande parte da sua região. Antes da minha pesquisa, eu tinha aquela ideia até um pouco romantizada, de que os aquíferos estariam em segurança, dada a sua profundidade, alguns cercados nas profundezas por rochas, mas que no decorrer das minhas leituras percebi tristemente que essa não é a realidade, já está havendo uma contaminação dos aquíferos, principalmente por agrotóxicos.

Leonardo Melgarejo - Eu tenho lido sobre o aquífero Guarani. E uma das coisas mais impactantes que me chegou nos últimos tempos é que o aquífero Guarani já não é mais considerado um recurso natural renovável. Porque a retirada de água do aquífero é maior do que a capacidade de reposição e haveria um horizonte de renovação associado a 500 anos, haveria um horizonte de renovação que permitiria sua classificação como um recurso natural renovável. E ele está perdendo. Nos últimos cinquenta anos perdeu 120 metros, se não me engano, em algumas áreas de captação, e São José do Rio Preto é um dos pontos de captação no interior de São Paulo.

Andreia Couto - Araraquara, também, recentemente entrevistei um pesquisador que afirmou que nesses últimos períodos de seca aqui no interior de São Paulo, a região de Araraquara também está bombeando água do Aquífero e São José do Rio Preto inaugurou uma estação recentemente para retirar água do aquífero.

\footnotetext{
${ }^{7}$ Líder indígena Txai Suruí, que discursou na COP 26.
}

\section{Revista ALTERJOR}

Grupo de Estudos Alterjor: Jornalismo Popular e Alternativo (ECA-USP)

Ano 12 - Volume 01 - Edição 25 - Janeiro-Junho de 2022 
Leonardo Melgarejo - E isso tem algumas implicações, são muitas as implicações, mas veja duas: a primeira é que o nível de água vai baixando e à medida que se reduz o volume de água aumenta a concentração de tudo o que está diluído nesta água, não é? E nós estamos jogando um bilhão de litros de agrotóxicos por ano no território nacional, todo ano. E isso desce. Segue a lei da gravidade, vai parar nos aquíferos. E se é crescente o volume do veneno jogado e é decrescente o volume da água em que esse veneno é diluído, daqui a pouco esses aquíferos serão envenenados.

Andreia Couto - Tóxicos?

Leonardo Melgarejo - Tóxicos! É inevitável essa conta. Eles tendem a ser tóxicos. Então nós temos que parar de jogar veneno neles porque é a única maneira, não há como limpar, filtrar, “dessalinizar” o aquífero. É uma conclusão terrível e lógica. Inevitável, nós temos que adotar a agroecologia.

Andreia Couto - E no caso das fontes de água mineral, elas ainda estão protegidas?

Leonardo Melgarejo - Não, a regra é a mesma, a lei da gravidade faz com que tudo o que é jogado, desça. E o veículo de transporte de tudo o que desce é a água. E nos lugares onde essa água se acumula vai se acumular tudo aquilo que desce diluído na água. Aquilo que tu comentou também do aquífero Guarani, para mim foi uma surpresa quando eu fiquei ciente de que o aquífero Guarani não seria um lago subterrâneo e sim rochas esponjosas que têm dentro delas essa água, o que significa impossibilidade de limpar. A gente pode teoricamente limpar um açude ou uma piscina chupando a água, filtrando e devolvendo, mas isso que está dentro de rochas, a umidade retida dentro de rochas não tem como. Bom, a saída é trabalhar com o princípio da precaução, preventivamente, antes que o problema se torne mastodôntico. Se a gente está percebendo que esse problema cresce ... Eu parei de fumar porque o médico me disse, "tu vai morrer". Esse processo é gradativo. Só tem uma alternativa, cortar a curva de crescimento. Com os agrotóxicos é a mesma coisa.

Andreia Couto - Além dessa dificuldade toda, nós vivemos um momento nesse país, um momento terrível e que é até difícil conversar com as pessoas e há esse negacionismo todo em relação a questões fundamentais e aí fica complicada essa conscientização, ela esbarra num discurso governamental que varre tudo isso. É o desmonte dos órgãos de pesquisa, das universidades públicas, da pesquisa...então ...fica difícil, porque sem dinheiro, como se faz pesquisa, não é?

\section{Revista ALTERJOR}

Grupo de Estudos Alterjor: Jornalismo Popular e Alternativo (ECA-USP)

Ano 12 - Volume 01 - Edição 25 - Janeiro-Junho de 2022

Av. Professor Lúcio Martins Rodrigues, 443, Cidade Universitária, São Paulo, CEP: 05508-020 


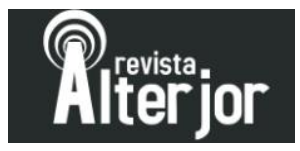

Leonardo Melgarejo - Mas sejamos otimistas, a ministra Carmem Lúcia do STF, deu um voto a favor da lei que pró́be a pulverização aérea de agrotóxicos no Ceará. Maravilhoso! As informações que nós temos é que existem 15 municípios no Brasil e um Estado onde é proibida a pulverização aérea. E todas essas proibições estão sendo questionadas no Supremo Tribunal Federal e esse voto da ministra Carmem Lúcia, e que foi seguido pelo Fachin, é maravilhoso, porque isso significa que a conscientização está chegando, não é dominante no STF, mas está chegando lá. Com o tempo se tornará dominante.

Andreia Couto - Tem o caso terrível e emblemático da cidade Lucas do Rio Verde.

Leonardo Melgarejo - Sim. Nós temos muitos casos emblemáticos. Aqui no Rio Grande do Sul, em Santa Rita, ao lado de Porto Alegre, é um caso emblemático. Nós temos muitos, e temos esse processo de conscientização, que é gradativo, que avança, e temos as pessoas que estão ocupando postos de representação que agem de maneira contrária ao bom senso, mas elas vão ser substituídas. Talvez tu e eu não vejamos isso, mas uma próxima geração vai ser confrontada com a necessidade.

Andreia Couto - Sobre a representação. A questão dos agrotóxicos é defendida no governo, no Congresso, existe lá o lobby do agrotóxico e como vamos fazer frente a isso, elegendo pessoas que vão enfrentar essa bancada. E eu li recentemente que o MST está querendo eleger pessoas para ocupar cadeiras no Congresso. Eu achei interessante, porque eu trabalhei no meu doutorado sobre a agricultura familiar em assentamentos rurais de reforma agrária e eu visitei vários, inclusive na região Sul, e a produção deles é pautada na produção orgânica. Creio que esse seria um passo importante para fazer frente a essa bancada do veneno.

Leonardo Melgarejo - Esse processo de conscientização a respeito das necessidades na alteração em formas de viver e trabalhar, ele vem acontecendo em todos os espaços, vem acontecendo no STF assim como vem acontecendo na Agricultura familiar. O que o MST percebeu e que já era anunciado por pessoas há mais tempo é que o agricultor de pequeno porte que tem uma área relativamente pequena, ele só tem uma alternativa de se manter e reproduzir: proteger e ampliar a fertilidade do solo. E para isso ele tem que parar de envenenar o solo. A Ana Maria Primavesi ${ }^{8}$ afirmava que o solo é um ser vivo. E sendo um ser vivo, ele não pode ser estimulado a processos deletérios, ele não pode adoecer. Ela dizia, "um solo são é condição fundamental para plantas sadias e as plantas sadias são condições fundamentais para animais sadios e disso para sociedades sadias".

\footnotetext{
${ }^{8}$ Pioneira da agroecologia no Brasil.
}

Revista ALTERJOR

Grupo de Estudos Alterjor: Jornalismo Popular e Alternativo (ECA-USP)

Ano 12 - Volume 01 - Edição 25 - Janeiro-Junho de 2022

Av. Professor Lúcio Martins Rodrigues, 443, Cidade Universitária, São Paulo, CEP: 05508-020 
Esse é o princípio que o MST incorporou aos seus assentamentos. Nós precisamos estabelecer um pacto de relação com as sociedades onde nós oferecemos alimentação sadia e eles adquirem esses produtos para que a gente possa preservar a fertilidade do solo. E isso pode ser feito em larga escala, e isso seria mais fácil com o apoio de instituições de pesquisa, como a Embrapa. Está sendo mais lento porque esse processo de conscientização desaloja verdades, desaloja paradigmas e porque as pessoas estão procurando o controle, é o que está em disputa, o João Pedro Stédile fala muito da correlação de forças para traduzir isso, o controle está em disputa e pessoas como a Kátia Abreu respondem a um determinado grupo, que têm determinados interesses que para se manterem precisam de uma determinada aceitação de valores. Eu acredito que, assim como tu, assim como eu, assim como a Kátia Abreu, todos nós queremos representantes que trabalhem em defesa dos nossos valores. No caso do MST, imagino que tu está se referindo ao que vai acontecer aqui no Rio Grande do Sul, onde o candidato ao governo de estado é o Edegar Pretto, que é um deputado estadual que há bastante tempo ele vem sendo o deputado mais votado do PT do Rio Grande do Sul e que é o candidato ao governo de Estado. Ele sem dúvida tem um compromisso com a agricultura familiar de pequeno porte; ele sem dúvida tem um compromisso com esses valores de preservação da vida do solo, de preservação da água. Não é só o MST que quer eleger pessoas que têm esses valores, eu também quero.

Andreia Couto - A agroecologia é vista como uma saída. E voltando à Kátia Abreu, eu assisti a um discurso dela no Congresso defendendo os agrotóxicos e falando que, se todo mundo quisesse comer orgânicos no Brasil, nós íamos precisar de três, cinco brasis. Ou seja, na visão dela, é o agronegócio que vai dar conta de alimentar do mundo, mesmo porque sabemos que o agronegócio não produz comida, quem produz comida é o pequeno agricultor. Precisamos mudar esse discurso, dizer que a agroecologia é possível, sim.

Leonardo Melgarejo - Esse discurso [do agronegócio] é um discurso falso e mentiroso e a gente só não consegue desmontar ele porque nós não temos os mesmos espaços. Existem livros do tipo de um que foi muito comercializado no Brasil que diz "agradeça aos agrotóxicos por estar vivo". Ele foi muito vendido porque ele era comprado e distribuído e foi produzido por interesses relacionados a esse tipo de propaganda. Não significa que tenha um valor real, significa que ele segue aquela lógica de que tudo aquilo que é muito repetido acaba sendo muito aceito.

Andreia Couto - Em uma de suas palestras, o senhor fala sobre as questões geopolíticas que nos conduz a sermos os produtores das commodities. Mesmo que aqui no Brasil houvesse um governo, ou que futuramente haja um governo, ou que voltemos

\footnotetext{
Revista ALTERJOR

Grupo de Estudos Alterjor: Jornalismo Popular e Alternativo (ECA-USP)

Ano 12 - Volume 01 - Edição 25 - Janeiro-Junho de 2022

Av. Professor Lúcio Martins Rodrigues, 443, Cidade Universitária, São Paulo, CEP: 05508-020
} 


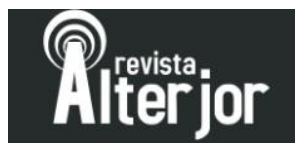

a ter um governo mais interessado em questões sociais, ainda assim haveria uma pressão internacional para que nós continuássemos a ser o que somos: os grandes produtores de soja para exportação. Seria uma questão que independe do contexto da política interna, nós seremos sempre pressionados internacionalmente a sermos o que somos?

Leonardo Melgarejo - Nós seremos enquanto nós formos colônia do império. Um discurso que temos escutado muito recentemente é de que a geopolítica internacional está agora dividida em dois grandes players, os Estados Unidos e a China, e que os militares que estão no governo Bolsonaro acreditam que, como nós temos mais afinidade com os valores norte-americanos, nós temos uma condição mais favorável de nos aliarmos subalternamente aos Estados Unidos, ao invés de corrermos o risco de sermos vassalos da China. E essa é uma visão muito simplificada, porque nós podemos ser um terceiro bloco. Nós podemos ser um bloco que envolve todos esses países que são vassalos ou dos Estados Unidos ou da China, só aqui na América do Sul existe a maior riqueza do planeta que é a disponibilidade de água, biodiversidade, existe tudo aquilo que não conhecemos ainda. E numa parceria com esses países, nós podemos formar um terceiro bloco que pode disputar essa geopolítica internacional de uma maneira menos subalterna. Eu gostaria de dizer para a Kátia Abreu, se tivesse a oportunidade algum dia, que de fato o nosso PIB depende da soja, que de fato a soja é uma commodity de grande valor nos negócios internacionais e que de fato, a soja consegue ser comercializada no mercado de capitais várias vezes antes de ser consumida porque o mercado futuro de direitos sobre colheita ele também é um mercado futuro sobre direitos de plantio. Safras futuras já estão sendo comercializadas. E, no entanto, nós não temos sementes. As sementes são de meia dúzia de empresas e sem as sementes nós não podemos honrar esses negócios de contrato futuro. Portanto, é uma ilusão muito grande acreditar que esse agronegócio é nosso e que a nossa pujança depende desse agronegócio que é nosso, na verdade seria assim se nós tivéssemos uma outra política que os agricultores pudessem guardar e multiplicar as suas sementes, se esse fosse o objetivo das instituições de pesquisa. Embora a Kátia Abreu e os defensores do agronegócio falem que essas sementes transgênicas são mais produtivas, essa é uma afirmativa irresponsável porque as sementes transgênicas não são modificadas para aumentarem a produtividade, e sim para não morrerem com um banho de herbicida. Para facilitar tratos culturais. Elas ganham produtividade com base nas pesquisas tradicionais que examinam uma relação de co-evolução entre as plantas e o clima. Hoje já não se fala mais tanto em genéticas, se fala em epigenética ${ }^{9}$ como sendo uma relação

\footnotetext{
9 “A epigenética compreende um conjunto de mecanismos que promovem a regulação da expressão gênica a nível transcricional através de modificações químicas no DNA e na cromatina, como metilação,
}

Revista ALTERJOR

Grupo de Estudos Alterjor: Jornalismo Popular e Alternativo (ECA-USP)

Ano 12 - Volume 01 - Edição 25 - Janeiro-Junho de 2022

Av. Professor Lúcio Martins Rodrigues, 443, Cidade Universitária, São Paulo, CEP: 05508-020 


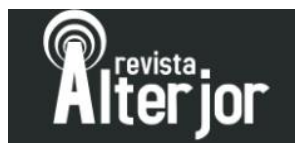

entre a capacidade de respostas às possibilidades de produção do genoma em função de um ambiente que está se alterando, que ativa e desativa mecanismos internos. E essa curva de produtividade decorre dessa seleção de plantas em função do ambiente, que depois são transformadas em plantas transgênicas tolerantes, por exemplo, ao herbicida. E quando essa transformação se dá, essas plantas passam a ser patenteadas, passam a ter um direito de propriedade intelectual sobre a transformação genética.

Andreia Couto - Seria o que a Revolução Verde fez com o milho híbrido?

Leonardo Melgarejo - É diferente, é um passo adiante do híbrido. De qualquer maneira, é um passo atrás em relação à evolução da agricultura, que correspondia a cada agricultor escolher o melhor resultado de hoje para plantar no ano seguinte.

Andreia Couto - Nós podemos dizer que a combinação agrotóxico + OGM é uma bomba?

Leonardo Melgarejo - É uma bomba. Nós podemos dizer que é uma bomba. Eu vejo uma bomba como uma coisa que estoura, mas no caso, é uma bomba que se derrama, que gera novas necessidades. Exemplo: a soja transgênica tolerante ao glifosato. Em seguida surgem plantas que não morrem com glifosato porque o uso continuado do veneno gera uma pressão seletiva que induz ao surgimento de mutação para a sobrevivência na presença daquele veneno. Isso significa que para matar as plantas que estão dento da lavoura de soja e de milho, é preciso jogar um outro veneno, que também mataria a soja ou o milho. Então é preciso uma nova geração de soja ou de milho geneticamente modificada para não morrer com o outro veneno, e assim sucessivamente com outro, com outros, com outros... Uma das plantas transgênicas mais modernas aprovadas no Brasil é o milho tolerante ao $2,4 \mathrm{D},{ }^{10}$ ao glifosato, é tolerante a um monte

acetilação e fosforilação, que resultam na consequente mudança fenotípica do indivíduo sem, no entanto, ocorrer nenhuma alteração na sequência do DNA" (COSTA e PACHECO, 2013, 1).

10 Ácido 2,4 Diclorofenóxiacético. De acordo com Bester et al., 2020 (portal Periódicos, da Universidade Federal de Santa Maria - https://periodicos.ufsm.br/remoa/article/view/39624/html), o 2,4D é "um herbicida produzido durante o a segunda Guerra Mundial (1939-1945), no contexto da guerra química e biológica, foi utilizado também na guerra do Vietnã (1954-1975), um composto conhecido como agente laranja, que era utilizado como desfolhante das florestas vietnamitas. (...) Segundo Neto et AL, (Apud BESTER et al., 2020), atribui-se ao 2,4-D a classificação toxicológica máxima (Classe I) que, em animais, se refere à DL50 (dose letal que elimina 50\% de uma população) por via oral entre 0-50 mg kg1; por via dérmica entre 0-200 mg kg-1; CL50 (concentração letal que elimina 50\% de uma população) por via respiratória entre 0-0,2 mg L-1 e irritação para pele e olhos classificada como severa" (NETO et NETO et al. Avaliação do transporte do ácido 2,4-diclorofenoxiacético através de um lisímetro. Quím. Nova, vol.35 no. 9 São Paulo, 2012. 2012).

Revista ALTERJOR

Grupo de Estudos Alterjor: Jornalismo Popular e Alternativo (ECA-USP)

Ano 12 - Volume 01 - Edição 25 - Janeiro-Junho de 2022

Av. Professor Lúcio Martins Rodrigues, 443, Cidade Universitária, São Paulo, CEP: 05508-020 


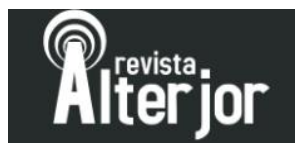

de veneno. O que induz o agricultor a misturar esses venenos dentro do tanque do pulverizador gerando uma calda tóxica sobre a qual nós não temos informações de impacto sobre a saúde. É uma bomba, é um fluxo que chama novas gerações do veneno, novas gerações da tecnologia. É um discurso em que o problema gera novos problemas, que gera novas soluções, que trazem novos problemas. Nós precisamos interromper o processo.

Andreia Couto - A música Fado Tropical, do Chico Buarque, diz o seguinte na estrofe: "Ai, esta terra ainda vai cumprir o seu ideal/ Ainda vai tornar-se o imenso Portugal Ai, esta terra ainda vai cumprir o seu ideal/Ainda vai tornar-se o Império Colonial"

Eu costumava dizer que "essa terra - Brasil - ainda vai cumprir seu ideal /ainda vai se transformar em um imenso canavial”, numa metáfora à expansão do agronegócio monocultor. E eis que estamos nesse caminho, não é?

Leonardo Melgarejo - Estamos sim. Uma das joias da coroa da Kátia Abreu quando era ministra era o Matopiba, um acrônico que junta as palavras Maranhão, Tocantins, Piauí e Bahia. E lá no Matopiba seria a nossa pátria sojeira, com estradas de ferro, com portos de escoamento, uma área com a soma da Itália e da Alemanha, uma área onde há dezenas de nações indígenas, quilombolas, agricultores familiares, vários municípios que seriam todos transformados na Meca da soja, e a Kátia Abreu defendeu isso durante muito tempo, e muita gente ainda defende isso como sendo uma das alternativas para o Brasil. Homogeneizar numa imensa lavoura de soja, nessa linha aí de essa terra se transformar em um imenso "canavial", uma lavourona de soja.

Andreia Couto - A expansão da fronteira agrícola em direção ao Norte, que avança sobre a floresta, simplisticamente falando, são produtores do agronegócio que estão avançando, tomando posse, na verdade, de um espaço que é do Estado. Eles não estão comprando terra na floresta, não é? Estão avançando sobre uma terra pública.

\section{Leonardo Melgarejo - Sim.}

Andreia - E não há essa percepção pública. A mídia fala, sempre que há uma ocupação de terras improdutivas pelo MST, de "invasão", mas não toca nessas verdadeiras invasões que o agronegócio promove sobre a floresta.

Leonardo Melgarejo - É verdade. A palavra “invasão", por exemplo, é utilizada pela mídia por ocasião das ações do MST desconsiderando que na versão da via campesina, na versão do MST, o que se dá é uma ocupação de uma área improdutiva. Mas enfim, esse avanço do agronegócio é um avanço de algo maior do que o agronegócio. Porque

\section{Revista ALTERJOR}

Grupo de Estudos Alterjor: Jornalismo Popular e Alternativo (ECA-USP)

Ano 12 - Volume 01 - Edição 25 - Janeiro-Junho de 2022

Av. Professor Lúcio Martins Rodrigues, 443, Cidade Universitária, São Paulo, CEP: 05508-020 


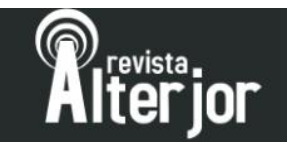

num primeiro momento há uma devastação das comunidades que ali estão, cooptação, morte, expulsão. Depois há a destruição das outras formas de vida que sobrevivem naquele território, limpando para o pasto andar. E depois do pasto vem a mineração, que esteriliza o solo, é um processo de "esterilização" de uma região biodiversa. É um processo predatório que tem vários degraus. $\mathrm{O}$ caso do avanço dos garimpeiros se inverte um pouco por causa da presença do ouro, porque onde não se encontra um recurso que concentra tanto valor, o avanço é mais gradativo, começa com o fogo, depois vende o carvão... Primeiro liquida as pessoas, o tecido social. Depois vende o carvão, depois vem o pasto, depois vem o boi, depois vem o minério mais barato, tipo o minério de ferro, os metais não tão valiosos. E a gente consome água para exportar. $\mathrm{O}$ alumínio sai do Pará e vai até os portos no litoral dentro de grandes tubos, carregados, impulsionados por água. Água, que é o bem mais precioso que nós temos usado como veículo de transporte para minério.

Andreia Couto - Nós estamos exportando água, nesse sentido.

Leonardo Melgarejo - Nós estamos exportando água. Mas tu vê, teu tema é tão interessante, e isso é muito raro na pesquisa científica que é lidar com conversas agradáveis, com conversas que se estendem. E por isso ele é muito delicado, ele é muito difícil de ser trabalhado. Ele pode ser popularizado com relativa facilidade.

Andreia Couto - A intenção sobre o produto final da minha pesquisa é que ela seja disseminada o máximo possível, inclusive de forma digital.

Leonardo Melgarejo - As informações mais atualizadas só circulam em pdf, só circulam em livros digitais e isso nos enfraquece na disputa pelos discursos, porque sem acesso aos livros digitais, estamos num debate desigual com relação à grande mídia. Porque eles estão trabalhando com conceitos relativamente novos que só estão aparecendo nos livros digitais. Os transgênicos são coisas do passado, hoje existem, na engenharia genética, produtos chamados cisgênicos, que não envolvem a transferência de genes entre indivíduos e espécies não aparentadas, envolvem a manipulação do genoma do próprio indivíduo. Os defensores dessa tecnologia dizem que o que eles estão fazendo é acelerar um processo natural de adaptação dos organismos que ocorreria, só que ao invés de levar 500 anos, mil anos, estamos adiantando.

Andreia Couto - Estamos mexendo com coisas desconhecidas, cujos resultados nós desconhecemos.

Revista ALTERJOR

Grupo de Estudos Alterjor: Jornalismo Popular e Alternativo (ECA-USP)

Ano 12 - Volume 01 - Edição 25 - Janeiro-Junho de 2022

Av. Professor Lúcio Martins Rodrigues, 443, Cidade Universitária, São Paulo, CEP: 05508-020 
Leonardo Melgarejo - Pois é, mas as críticas a essas coisas que estão sendo feitas elas não são localizáveis nos sebos, nos livros do passado, elas só existem nessas publicações digitais de hoje. Esse seu trabalho, quando sair, vai trazer leituras novas que não se vai encontrar em publicações impressas.

Andreia Couto - Para finalizar, eu gostaria de trazer uma imagem que o senhor mencionou em uma de suas palestras: as raízes das plantas, lá no subsolo, elas se encontram, se entrelaçam, não necessariamente somente as raízes de plantas irmãs, mas de outras que se encontram na diversidade de uma floresta, de um bosque, a quantidade de raízes que se entrelaçam por exemplo. Achei uma imagem bonita e que temos que pensar nisso, não uma disputa, uma competição por espaço, mas de uma ajuda mútua, de cooperação, que seria, para nós, no fortalecimento de andarmos juntos nesse caminho tão árduo.

Leonardo Melgarejo - Pleno acordo! Essa imagem não é minha, devo ter visto, escutado em algum local e ao ver ou escutar em algum local entendi que quando dois seres se tocam existe um espaço que cada um dos seres compreende como sendo seu, mas que é mútuo. Nas plantas é fácil verificar isso porque há uma superfície coloidal nas raízes onde a comunicação permite troca de elementos de um para outro. E isso acontece também conosco, com as pessoas. Na medida em que a gente se comunica e se compreende em relação a um determinado assunto, existe um lado que é mútuo nessa compreensão. E esse algo que é mútuo nos faz um outro, nos faz um outro que é composto por esse toque, por essa conjunção. E acredito que está crescendo essa compreensão de que os seres são mais do que as partes. A gente se considera uma parte, uma parte individual, mas não, fazemos parte de um todo - de Gaia. Tem uma outra imagem que está associada a isso mesmo que diz respeito à água. Cada gota pode se imaginar uma gota, mas ela só existe no conjunto, só existe no todo. A água toda do planeta é uma coisa só.

Andreia Couto - Assim como o meio ambiente somos nós, nós somos parte dele.

Leonardo Melgarejo - Isso. E nós somos parte dele numa visão que está muito longe da nossa capacidade de perceber, nós somos parte dele no passado e o futuro. É o que fala o Krenak nesse pacto plurigeracional. Bem, é isso.

\section{Referências}

CARLSON, Rachel. Primavera Silenciosa. New York: Houghton Mifflin, 1962.

Revista ALTERJOR

Grupo de Estudos Alterjor: Jornalismo Popular e Alternativo (ECA-USP)

Ano 12 - Volume 01 - Edição 25 - Janeiro-Junho de 2022

Av. Professor Lúcio Martins Rodrigues, 443, Cidade Universitária, São Paulo, CEP: 05508-020 


\section{Anteior}

COSTA, Everton de Brito Oliveira e PACHECO, Cristiane. Epigenética: regulação da expressão gênica em nível transcricional e suas implicações. Semina: Ciências Biológicas e da Saúde, Londrina, v. 34, n. 2, p. 125-136, jul./dez. 2013. DOI: 10.5433/1679-0367.2013v34n2p125. Acesso 10/12/2021.

NETO et al. Avaliação do transporte do ácido 2,4-diclorofenoxiacético através de um lisímetro. Quím. Nova, vol.35 no. 9 São Paulo, 2012. https://doi.org/10.1590/S010040422012000900020. Acesso 30/11/2021 